\title{
Sistem Pendukung Keputusan Untuk menentukan Beasiswa pada SMA Panca Karya Tangerang Dengan Metode Profile Matching
}

\author{
Ibnu Dwi Lesmono \\ Universitas Bina Sarana Infromatika \\ e-mail: Ibnu.Idl@bsi.ac.id
}

\begin{abstract}
Abstraksi
Informasi yang berkualitas di butuhkan oleh manajemen untuk dapat mengambil keputusan yang tepat, karena kesalahan dalam mengambil keputusan dapat mengakibatkan sebuah kerugian baik moril maupun materil, oleh karena itu dibutuhkan sebuah sistem pendukung yang baik yaitu sistem yang dapat membantu manajemen mengambil keputusan yang tepat. Sistem Pendukung Keputusan adalah sebuah sistem komputer yang membantu para pengambil keputusan untuk mengambil keputusan yang sesuai, yang dapat memperhitungkan segala aspek penilaian yang di tentukan yang mendukung pengambilan keputusan guna membantu, mempermudah proses pengambilan keputusan. Ada banyak metode yang dapat di gunakan untuk membantu mengambil keputusan dan salah satunya adalah metode profile matching. Metode ini peneliti gunakan untuk menentukan dengan tepat siswa penerima beasiswa, Metode ini mampu menyeleksi alternative terbaik dari sejumlah alternatif, dalam hal ini yaitu yang berhak menerima beasiswa berdasarkan kriteria-kriteria yang telah ditentukan oleh pihak pemberi beasiswa yang dalam hal ini adalah SMA Panca Karya Tangerang yang peneliti ambil sebagai lokasi penelitian . Penelitian dilakukan dengan menentukan aspek dan sub aspek, mencari nilai bobot untuk setiap sub aspek, mencari GAP antara profil dengan keadaan data para siswa. Kemudian ditentukan presentasi kedua unsur aspek dan dijumlahkan kemudian dilakukan proses perankingan yang akan menentukan alternatif yang optimal, yaitu siswa dengan nilai tertinggi. Ada dua bentuk penerima beasiswa yang digunakan pada penelitian ini, yaitu berdasarkan ekonomi keluarga dan prestasi siswa. Penelitian ini hasilnya adalah berupa hasil rangking dari seleksi Metode Profile Matching berdasarkan kriteria yang telah di tentukan. Dengan demikian sistem ini diharapkan dapat membantu sekolah didalam menentukan siswa mana yang akan menerima beasiswa.
\end{abstract}

Kata Kunci: Siswa, Beasiswa, Profile Matching, Sistem Pendukung Keputusan

Abstract

Quality information needed by management to be able to make the right decision, because mistakes in making decisions can result in both moral and material losses, Decision Support System is a computer system that aims to help decision makers make appropriate decisions, which can take into account all aspects of the determined assessment that support decision making to help and facilitate the decision making process. There are many methods that can be used to help make decisions including the profile matching method. This method the author uses to determine precisely the scholarship recipient students, this method is able to select the best alternative from a number of alternatives, in this case that is entitled to receive scholarships based on criteria determined by the scholarship provider, in this case Panca Karya Tangerang High School. The study was conducted by determining aspects and sub-aspects as well as finding the weight value for each sub-aspect, looking for GAP between the profile and the state of the students' data. Then determined the presentation of the two aspects and added together then carried out the ranking process that will determine the optimal alternative, namely the student with the highest score. There are two forms of scholarship recipients used in this study, which are based on family economics and based on student achievement. The results of this study are ranking results from the Profile Matching Method selection based on the criteria that have been determined. Thus this system is expected to help the institution in determining students who will receive scholarships that are able to provide the solutions needed in making the right decision.

Keywords: Scholarships, Profile Matching, Decision Support System

Diterima Februari 8, 2020; Revisi Februari 11, 2020; Disetujui Maret 01, 2020 


\section{Pendahuluan}

Hampir semua bidang kehidupan saat ini dipengaruhi oleh penggunaan teknologi informasi. Teknonologi memang dikembangkan untuk mendukung berbagai macam ilmu pengetahuan. Teknologi yang semakin canggih dan berkembang pesat telah merubah berbagai aspek kehidupan. teknologi informasi mempengaruhi dunia bisnis, politik, sosial perekonomian juga mempengaruhi dunia pendidikan. Sistem pendukung keputusan adalah sekumpulan elemen yang saling berhubungan untuk membentuksuatu kesatuan dalam proses pemilihan berbagai alternatif tindakan guna menyelesaikan suatu masalah, sehingga masalah tersebut dapat diselesaikan secara efektif dan efisien (Hardianti, Hidayatullah, Pratiwi, \& Hadiansa, 2017). Salah satunya adalah informasi yang dapat mempermudah dan membantu pengambilan keputusan dalam menentukan calon penerima beasiswa. Beasiswa dapat dikatakan sebagai pembiayaan yang tidak bersumber dari pendanaan sendiri atau orang tua, akan tetapi diberikan oleh pemerintah, perusahaan swasta, kedutaan, universitas, serta lembaga pendidik atau peneliti, atau juga kantor tempat bekerja yang karena prestasi seseorang dapat diberikan kesempatan untuk meningkatkan kapasitas sumber daya manusianya melalui pendidikan (Junaidi \& Visella, 2017). SMA Panca Karya Tangerang yang telah memiliki program pemberian beasiswa bagi siswa, terkait dengan pengelolaan beasiswa siswa yang masih menggunakan sistem manual tentunya akan mengalami kesulitan, karena banyaknya siswa yang berhak mendapatkan beasiswa dan terdapat beberapa aspek yang digunakan untuk menentukan keputusan penerima beasiswa bagi siswa yang sesuai dengan yang diharapkan. Ada dua kategori penerima beasiswa di SMA Panca Karya Tangerang, yakni: siswa miskin dan siswa berprestasi. Dengan menggunakan metode profile matching diharapkan mampu menyeleksi siswa yang berhak menerima beasiswa berdasarkan kriteria-kriteria yang ditentukan. Penelitian dilakukan dengan menentukan aspek dan sub aspek berserta mencari nilai bobot untuk setiap sub aspek, mencari gap (selisih) antara profil dengan keadaan data dari siswa dengan menggunakan metode ini ditentukan presentasi kedua unsur aspek dan dijumlahkan kemudian dilakukan proses yang optimal, yaitu siswa dengan nilai tertinggi.

Penelitian yang pernah dilakukan oleh (Angkasa, 2017) menggunakan AHP, membahas mengenai penentuan calon penerima beasiswa siswa di STMIK Indonesia banjarmasin dengan menggunakan kriteria penghasilan orang tua, rata-rata nilai rapor, tingkat kejuaraan, dan kegiatan ekstra kurikuler.

Dan penelitian terdahulu menggunakan metode profile matching pernah dibuat oleh (Sugiartawan, Rowa, \& Hidayat, 2018) membahas tentang penentuan kenaikan jabatan.

Sistem pendukung keputusan adalah sistem informasi interaktif yang menyediakan informasi, pemodelan dan pemanipulasian data. Sistem itu digunakan untuk membantu pengambilan keputusan dalam situasi yang semiterstruktur dan situasi yang tidak terstruktur, dimana tak seorang pun tahu secara pasti bagaimana keputusan seharusnya dibuat (Ayulestari, Farlina, Yulistria, \& Susilawati, 2019). Sistem Pendukung Keputusan (Decision Support Systems) merupakan sebuah sistem yang dimaksudkan untuk mendukung para pengambil keputusan manajerial dalam situasi keputusan semi terstruktur (Angeline, 2018). Menurut (Apriana, 2019) metode profile matching atau pencocokan profil adalah metode yang sering digunakan sebagai mekanisme dalam pengambilan keputusan dengan mengasumsikan bahwa terdapat tingkat variabel prediktor yang ideal yang harus dipenuhi oleh subyek yang diteliti, bukan tingkat minimal yang harus dipenuhi atau dilewati. .

\section{Metode Penelitian}

Profile Matching

Profile Matching adalah sebuah mekanisme pengambilan keputusan dengan mengasumsikan bahwa terdapat tingkat minimal yang harus dipenuhi atau dilewati (Sudarmadi, Santoso, \& Sutrisno, 2017).

Langkah-langkah dalam penyelesaian perhitungan dengan menggunakan metode Profile Matching yaitu:

1. Aspek Penilaian.

Langkah pertama yang harus dilakukan yaitu menentukan aspek-aspek penilaian pada core factor (faktor utama) dan secondary factor (faktor kedua).

2. Pemetaan GAP Kompetensi 
GAP kompetensi adalah perbedaan antara kriteria yang dimiliki seseorang dengan kriteria yang diinginkan. Rumus GAP kompetensi yaitu:

GAP = Nilai Kriteria - Nilai Minimal

3. Pembobotan

Apabila pemetaan GAP sudah selesai dilakukan, maka hasil dari pemetaan tersebut diberi bobot nilai sesuai dengan patokan tabel bobot nilai GAP.

\section{A. Pengumpulan Data}

Data para siswa penerima beasiswa pada tahun-tahun sebelumnya dikumpulkan secara langsung dari lokasi penelitian yakni SMA Panca Karya Tangerang. Data yang ada akan dijadikan sebagai sumber pengetahuan bagi sistem pendukung keputusan ini. Pihak sekolah juga menentukan Core factor, Secondary Factor, dan nilai dari aspek- aspek yang digunakan dalam penelitian ini.

1. Analisis Kasus

Data yang telah dikumpulkan dianalisis sebelum diimplementasikan ke dalam sistem pendukung keputusan. Metode profile matching digunakan karena ada kesesuaian antara metode ini dengan metode seleksi penerima beasiswa yang dilakukan di sekolah.

2. Perancangan Aplikasi

Rancang bangun dari aplikasi ini akan dibuat berbasis web. Oleh karena itu, perancangan sistem yang dibuat akan menggunakan diagram konteks dan juga diagram alir data.

3. Pengujian Aplikasi

Pengujian dilakukan setelah aplikasi berhasil dibangun, dengan cara membandingkan hasil keputusan dari sekolah dan hasil perhitungan berdasarkan aplikasi.

\section{B. Kebutuhan Input}

Penelitian membutuhkan masukan (input) berupa: data siswa, data kriteria, data aspek, data nilai akademik, data nilai non akademik

\section{Kebutuhan Output}

Hasil yang akan diperoleh (output) berupa: laporan siswa yang menerima beasiswa, laporan data presentase siswa, laporan data siswa

\section{Diagram Konteks dan Diagram Alir Data Level Satu}

Model fungsional menggambarkan bagaimana masukan diproses oleh sistem menjadi keluaran yang diharapkan oleh JURNAL SWABUMI Vol.8 No.1, Maret 2020: 37-45 pengguna. Model fungsional memuat beberapa aliran data atau data flow diagram (DFD) yang memperlihatkan aliran data dari luar sistem yang kemudian diproses oleh sistem dan akhirnya menghasilkan keluaran yang berguna. Diagram konteks yang diterapkan pada aplikasi ini dapat dilihat pada Gambar 1. Sistem berinteraksi dengan admin dan pimpinan. Sistem ini menerima input berupa data calon siswa calon penerima beasiswa, kriteria, nilai akademik, nilai non akademik dan data aspek. Setelah semua data telah diinput, maka pimpinan memberikan nilai presentasi aspek dan nilai core factor dan secondary factor untuk menentukan calon penerima beasiswa. Sedangkan output yang dihasilkan berupa laporan untuk pimpinan. Lebih jelasnya mengenai sistem ini dapat dilihat pada DAD level satu pada Gambar 2.

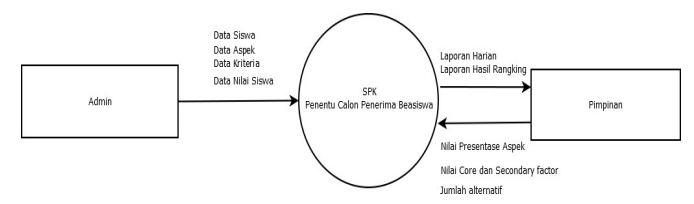

Gambar. 1. Diagram Konteks

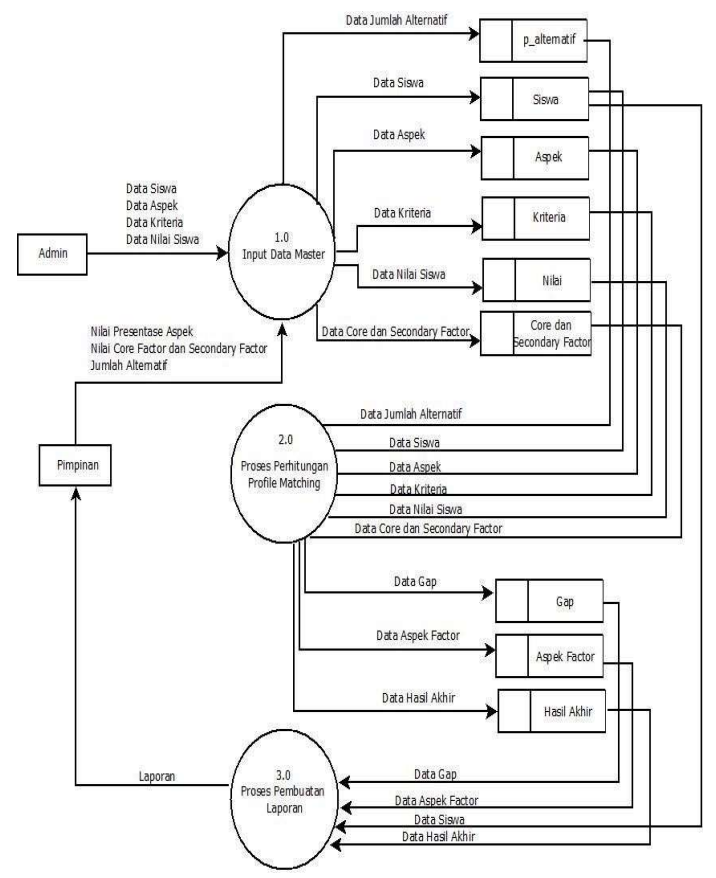

Gambar 2. Diagram Alir Data Level 1

Dalam memproses semua data siswa diperlukan adanya sebuah basis data untuk 
menampung data-data tersebut.

Adapun perancangan skema basis data dari penelitian ini dapat dilihat pada Gambar 3.

1) Profil Ideal/Nilai Standar Profil Ideal / Nilai Standar yang digunakan dan telah ditentukan oleh pihak sekolah adalah seperti yang tampak pada Tabel I dan Tabel II.

2) Nilai Core Factor dan Secondary Factor

Nilai core factor dan secondary factor yang telah ditentukan oleh pihak sekolah adalah: core factor sebesar $60 \%$ dan nilai secondary factor sebesar $40 \%$ dengan pembagian seperti yang tampak pada Tabel III dan Tabel IV.

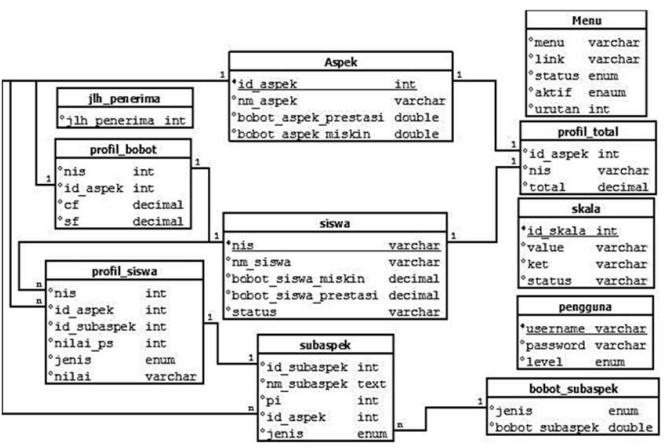

Gambar 3. Skema Basis Data

Tabel 1

Nilai Standar Aspek Ekonomi Keluarga

\begin{tabular}{lll}
\hline Status Siswa & & $\begin{array}{l}\text { Nilai } \\
\text { Standar }\end{array}$ \\
\hline Status Anak & 8 & \\
Pekerjaan Ayah & 8 \\
Pekerjaan Ibu & 8 \\
Penghasilan & 9 \\
Orang Tua & \\
Tanggungan & 9 \\
Orang Tua &
\end{tabular}

Tabel 2

Nilai Standar_Aspek_Akademik Prestasi

Mata Pelajaran

Nilai Standar

Agama \& Budi Pekerti 9

PKN 9

Bahasa Inggris

$\begin{array}{lr}\text { Matematika } & 8 \\ \text { IPA } & 8 \\ \text { IPS } & 8 \\ \text { Seni Budaya } & 8 \\ \text { Prakarya } & 8 \\ \text { Penjas } & 8 \\ \text { Bahasa Indonesia } & 8 \\ \text { Prestasi } & \text { Non } 7 \\ \text { Akademik } & \\ \text { Prestasi Akademik } & 8\end{array}$

Tabel 3

Penentuan Core Factor \& Secondary Factor Aspek Ekonomi Keluarga

\begin{tabular}{ll}
\hline Status Siswa & $\begin{array}{c}\text { Penentuan Core } \\
\text { Factor \& } \\
\text { Secondary } \\
\text { Factor }\end{array}$ \\
\hline $\begin{array}{l}\text { Status Anak } \\
\text { Pekerjaan Ayah }\end{array}$ & $\begin{array}{l}\text { Core Factor } \\
\text { Secondary } \\
\text { Fekerjaan Ibu }\end{array}$ \\
$\begin{array}{l}\text { Factor } \\
\text { Penghasilan Orang } \\
\text { Tua } \\
\text { Tanggungan Orang } \\
\text { Tua }\end{array}$ & $\begin{array}{l}\text { Factor } \\
\text { Core Factor }\end{array}$ \\
\hline
\end{tabular}

Tabel 4

Penentuan Core Factor \& Secondary Factor Aspek Akademik Prestasi

\begin{tabular}{|c|c|}
\hline Mata Pelajaran & $\begin{array}{l}\text { Penentuan } \\
\text { Core Factor \& } \\
\text { \& Secondary } \\
\text { Factor }\end{array}$ \\
\hline Agama \& Budi & Secondary \\
\hline Pekerti & Factor \\
\hline PKn & $\begin{array}{l}\text { Secondary } \\
\text { Factor }\end{array}$ \\
\hline Bahasa Inggris & Core Factor \\
\hline Matematika & Core Factor \\
\hline IPA & Core Factor \\
\hline IPS & Core Factor \\
\hline Seni Budaya & $\begin{array}{l}\text { Secondary } \\
\text { Factor }\end{array}$ \\
\hline Prakarya & $\begin{array}{l}\text { Secondary } \\
\text { Factor }\end{array}$ \\
\hline Penjas & $\begin{array}{l}\text { Secondary } \\
\text { Factor }\end{array}$ \\
\hline Bahasa Indonesia & $\begin{array}{l}\text { Secondary } \\
\text { Factor }\end{array}$ \\
\hline $\begin{array}{l}\text { Prestasi Non } \\
\text { Akademik }\end{array}$ & $\begin{array}{l}\text { Secondary } \\
\text { Factor }\end{array}$ \\
\hline
\end{tabular}


Prestasi

Akademik

1) Pembobotan Aspek Beasiswa

Dari hasil wawancara dengah pihak sekolah SMA Panca Karya Tangerang, ditentukan hasil pembobotan untuk dapat memisahkan hasil beasiswa ekonomi keluarga (BSM) dan Beasiswa Akademik Prestasi pada aplikasi.

a) Pembobotan Beasiswa Aspek Ekonomi Keluarga

1. Aspek Ekonomi Keluarga $70 \%$

2. Aspek Akademik Prestasi $30 \%$

b) Pembobotan Beasiswa Aspek Akademik Prestasi

1. Aspek Akademik Keluarga $40 \%$

2. Aspek Ekonomi Prestasi $60 \%$

\section{Hasil dan Pembahasan}

\section{a. Analisis Pengujian Program}

Pengujian sistem dalam penelitian ini menggunakan perhitungan manual sebagai acuan perbandingan hasil manual dengan aplikasi yang dibuat. Pengujian ini dilakukan untuk melihat kecocokan dari hasil yang diperoleh antara aplikasi dengan manual.

\section{b. Hasil Perhitungan Manual}

Pada pengujian ini digunakan data siswa calon penerima beasiswa sesuai dengan kriteria yang telah ditetapkan, Berikut adalah perhitungan manual dengan data seperti yang tampak pada Tabel 5 .

Pada Tabel 5 dan Tabel 6 dapat dilihat bahwa profil siswa berprestasi untuk setiap kriteria yang digunakan adalah sebagai berikut: Agama $=9, P K n=9$, Bhs Inggris $=$ 8 , Matematika $=8$, IPA $=8$, IPS $=8$, Seni budaya $=8$, Prakarya $=8$, Penjas $=8$, Bahasa Indonesia $=8$, Prestasi NonAkademik $=7$, dan Prestasi Akademik $=8$. Selanjutnya pada Tabel 4 dan 5 hasil perhitungan gap untuk setiap alternatif, dengan cara mengurangkan nilai profil siswa dengan nilai profil siswa calon penerima beaiswa. Setelah mendapat datadata setiap aspek maka selanjutnya menghitung nilai total berdasar kan hasil nilai bobot CF dan SF dari setiap aspek dengan menggunakan bobot $\mathrm{CF}=60 \%$ dan $\mathrm{SF}=40 \%$.

Pada Tabel 7 dan Tabel 8 adalah tabel data dari perhitungan bobot yang sudah ditentukan datanya dari setiap aspek antara lain aspek akademik dan aspek ekonomi keluarga. Setelah mendapat beberapa nilai yang di dapat dari masing-masing siswa penerima beasiswa yang menghasilkan nilai total berarti selanjutnya dilakukan perangkingan untuk menghitung dan mebandingan untuk menentetukan siapa penerima beasiswa dengan cara sebagai berikut:

Pada Tabel 9 adalah data akhir yang di peroleh dari pembobotan setiap aspek yaitu Nilai Ekonomi keluarga 30\% dan Akademik Prestasi $70 \%$ yang kemudian didapatlah hasil yang diperlukan untuk perankingan jika dilihat dari data perolehan hasil akhir maka bisa ditetapkan bahwa calon penerima beasiswa adalah Ahmad dan Heri karena jumlah penerima dapat diatur batasannya untuk dua orang penerima dari menu Jumlah Penerima pada aplikasi.

Pada Tabel 10 adalah data akhir yang diperoleh dari pembobotan setiap aspek yaitu Nilai Ekonomi keluarga $60 \%$ dan Akademik Prestasi $40 \%$ yang kemudian didapatkah hasil yang diperlukan untuk perankingan jika dilihat dari data perolehan hasil akhir maka bisa ditetapkan bahwa calon penerima beasiswa adalah Ahmad dan Heri karena jumlah penerima sudah ditetapkan kedalam sistem hanya dua orang penerima.Fitur ini disediakan di dalam aplikasi dan dapat diganti seperti yang tampak pada Gambar 4. Pada saat pemilihan beasiswa untuk contoh kasus Ahmad dan Heri jumlah penerimaditentukan untuk 2 orang, baik untuk beasiswa berprestasi dan beasiswa miskin. Pada Tabel V dan Tabel VI dapat dilihat bahwa profil siswa berprestasi untuk setiap kriteria yang digunakan adalah sebagai berikut: Agama $=9, P K n=9$, Bhs Inggris $=8$, Matematika $=8, \quad I P A=8, \quad I P S=8$, Seni budaya $=8$, Prakarya $=8$, Penjas $=8$, Bahasa Indonesia $=8$, Prestasi NonAkademik $=7$, dan Prestasi Akademik $=8$. Selanjutnya pada Tabel IV dan $\mathrm{V}$ hasil perhitungan gap untuk setiap alternatif, dengan cara mengurangkan nilai profil siswa dengan nilai profil siswa calon penerima beaiswa. Setelah mendapat data-data setiap aspek maka selanjutnya menghitung nilai total berdasar kan hasil nilai bobot CF dan SF dari setiap aspek dengan menggunakan bobot $\mathrm{CF}=60 \%$ dan $\mathrm{SF}=40 \%$.

Pada Tabel 7 dan Tabel 8 adalah tabel data dari perhitungan bobot yang sudah 
ditentukan datanya dari setiap aspek antara lain aspek akademik dan aspek ekonomi keluarga. Setelah mendapat beberapa nilai yang di dapat dari masingmasing siswa penerima beasiswa yang menghasilkan nilai total berarti selanjutnya dilakukan perangkingan untuk menghitung dan mebandingan untuk menentetukan siapa penerima beasiswa dengan cara sebagai berikut:

Pada Tabel 9 adalah data akhir yang di peroleh dari pembobotan setiap aspek yaitu Nilai Ekonomi keluarga 30\% dan Akademik Prestasi $70 \%$ yang kemudian didapatlah hasil yang diperlukan untuk perankingan jika dilihat dari data perolehan hasil akhir maka bisa ditetapkan bahwa calon penerima beasiswa adalah Ahmad dan Heri karena jumlah penerima dapat diatur batasannya untuk dua orang penerima dari menu Jumlah Penerima pada aplikasi. Pada Tabel 9 adalah data akhir yang diperoleh dari pembobotan setiap aspek yaitu Nilai Ekonomi keluarga

60\% dan Akademik Prestasi 40\% yang kemudian didapatkah hasil yang diperlukan untuk perankingan jika dilihat dari data perolehan hasil akhir maka bisa ditetapkan bahwa calon penerima beasiswa adalah Ahmad dan Heri karena jumlah penerima sudah ditetapkan kedalam sistem hanya dua orang penerima.Fitur ini disediakan di dalam aplikasi dan dapat diganti seperti yang tampak pada Gambar 4. Pada saat pemilihan beasiswa untuk contoh kasus Ahmad dan Heri jumlah penerimaditentukan untuk 2 orang, baik untuk beasiswa berprestasi dan beasiswa miskin.

\section{Seleksi Jumlah Penerima Beasiswa SMA Panca Karya Tangerang}

\begin{tabular}{|l|l|}
\hline $\begin{array}{l}\text { Jumlah Penerima } \\
\text { Beasiswa Prestasi }\end{array}$ & Aksi \\
\hline 23 orang & Edit \\
\hline
\end{tabular}

\begin{tabular}{|l|c|}
\hline $\begin{array}{l}\text { Jumlah penerima } \\
\text { Beasiswa Miskin }\end{array}$ & Aksi \\
\hline 20 orang & Edit \\
\hline
\end{tabular}

Gambar 4. Pemilihan Jumlah Penerima Beasiswa

Tabel 5

Tabel Aspek Prestasi Akademik

\begin{tabular}{|c|c|c|c|c|c|c|c|c|c|c|c|c|c|}
\hline NIS & $\begin{array}{l}\text { Nam } \\
\text { a }\end{array}$ & $\begin{array}{c}\text { Agam } \\
\text { a }\end{array}$ & $\begin{array}{l}\text { PK } \\
\mathbf{N}\end{array}$ & $\begin{array}{l}\text { Bhs } \\
\text { Inggri } \\
\text { s }\end{array}$ & $\begin{array}{l}\text { Mt } \\
\text { k }\end{array}$ & $\begin{array}{l}\text { IP } \\
\text { A }\end{array}$ & IPS & $\begin{array}{l}\text { Seni } \\
\text { Buday } \\
\text { a }\end{array}$ & $\begin{array}{l}\text { Pra } \\
k \\
\text { ary } \\
\text { a }\end{array}$ & $\begin{array}{l}\text { Penja } \\
\text { s }\end{array}$ & $\begin{array}{l}\text { Bh } \\
\text { s } \\
\text { Ind } \\
0\end{array}$ & $\begin{array}{l}\text { Pres. } \\
\text { Non } \\
\text { Akad }\end{array}$ & $\begin{array}{l}\text { Pre } \\
\text { s. } \\
\text { Aka } \\
\text { d }\end{array}$ \\
\hline 1111 & $\begin{array}{l}\text { Ahm } \\
\text { ad }\end{array}$ & 7 & 8 & 7 & 8 & 7 & 7 & 9 & 8 & 7 & 8 & 8 & 8 \\
\hline 1112 & Heri & 8 & 8 & 7 & 8 & 9 & 9 & 8 & 7 & 9 & 8 & 8 & 9 \\
\hline $\begin{array}{l}\text { Profil } \\
\text { ideal }\end{array}$ & & 9 & 9 & 8 & 8 & 8 & 8 & 8 & 8 & 8 & 8 & 7 & 8 \\
\hline 1111 & $\begin{array}{l}\text { Ahm } \\
\text { ad }\end{array}$ & -2 & -1 & - & 0 & -1 & -1 & 1 & 0 & -1 & 0 & 1 & 0 \\
\hline 1112 & Heri & -1 & -1 & - & 0 & 1 & 1 & 0 & -1 & 1 & 0 & 1 & 1 \\
\hline
\end{tabular}

Tabel 6

Contoh Aspek Ekonomi Keluarga

\begin{tabular}{|c|c|c|c|c|c|c|}
\hline NIS & $\begin{array}{l}\text { Nam } \\
\text { a }\end{array}$ & $\begin{array}{l}\text { Statu } \\
\text { s } \\
\text { Anak }\end{array}$ & $\begin{array}{r}\text { Pekerjaa } \\
\text { n Ayah }\end{array}$ & $\begin{array}{c}\text { Pekerjaa } \\
\text { n lbu }\end{array}$ & $\begin{array}{l}\text { Penghasil } \\
\text { an Orang } \\
\text { tua }\end{array}$ & $\begin{array}{l}\text { Tanggunga } \\
\text { n Orang } \\
\text { tua }\end{array}$ \\
\hline $\begin{array}{l}111 \\
1\end{array}$ & $\begin{array}{l}\text { Ahm } \\
\text { ad }\end{array}$ & 7 & 8 & 7 & 8 & 9 \\
\hline $\begin{array}{l}111 \\
2\end{array}$ & Heri & 7 & 8 & 8 & 9 & 8 \\
\hline
\end{tabular}




\begin{tabular}{|c|c|c|c|c|c|c|}
\hline $\begin{array}{l}\text { Prof } \\
\text { il } \\
\text { Ide } \\
\text { al }\end{array}$ & & 8 & 8 & 8 & 9 & 9 \\
\hline $\begin{array}{l}111 \\
1\end{array}$ & $\begin{array}{l}\text { Ahm } \\
\text { ad }\end{array}$ & -1 & 0 & -1 & -1 & 0 \\
\hline $\begin{array}{l}111 \\
2\end{array}$ & Heri & -1 & 0 & 0 & 0 & -1 \\
\hline
\end{tabular}

Tabel 7

Contoh Perhitungan Nilai Total Beasiswa Akademik

\begin{tabular}{|c|c|c|c|c|}
\hline NIS & $\begin{array}{l}\text { Nam } \\
\text { a }\end{array}$ & $\begin{array}{l}\text { Core } \\
\text { factor }\end{array}$ & $\begin{array}{l}\text { Secondary } \\
\text { factor }\end{array}$ & $\begin{array}{l}\text { Nilai } \\
\text { Total }\end{array}$ \\
\hline $\begin{array}{l}111 \\
1\end{array}$ & $\begin{array}{l}\text { Ahm } \\
\text { ad }\end{array}$ & 4.4 & 4.2 & 4.32 \\
\hline $\begin{array}{l}111 \\
2\end{array}$ & Heri & 4.5 & 4.4 & 4.46 \\
\hline
\end{tabular}

Tabel 8

Perhitungan Nilai Total Beasiswaekonomi Keluarga

\begin{tabular}{lllll}
\hline NIS & $\begin{array}{l}\text { Nam } \\
\text { a }\end{array}$ & $\begin{array}{l}\text { Core } \\
\text { factor }\end{array}$ & $\begin{array}{l}\text { Secondary } \\
\text { Factor }\end{array}$ & $\begin{array}{l}\text { Nilai } \\
\text { Total }\end{array}$ \\
\hline $\mathbf{1 1 1}$ & $\begin{array}{l}\text { Ahm } \\
\text { ad }\end{array}$ & 4.3 & 4.5 & 4.38 \\
$\mathbf{1 1 1}$ & Heri & 4.3 & 5 & 4.58 \\
$\mathbf{2}$ & & & & \\
\end{tabular}

A. Hasil Perhitungan Aplikasi

Adapun hasil uji coba dengan menggunakan data yang sama dengan menggunakan aplikasi yang dibangun dapat dilihat pada Gambar 5.

Tabel 9

Hasil Rangking Beasiswa Aspek Ekonomi Keluarga (Bsm)

\begin{tabular}{ccclc}
\hline NIS & Nama & $\begin{array}{l}\text { Nilai Aspek } \\
\text { Ekonomi } \\
\text { Keluarga }\end{array}$ & $\begin{array}{l}\text { Nilai Aspek } \\
\text { Prestasi } \\
\text { Akademik }\end{array}$ & Bobot \\
\hline $\mathbf{1 1 1 1}$ & Ahmad & 4.38 & 4.32 & 4.356 \\
$\mathbf{1 1 1 2}$ & Heri & 4.58 & 4.46 & 4.532 \\
\hline
\end{tabular}

Tabel 10

Hasil Rangking Beasiswa Aspek Akademik Prestasi

\begin{tabular}{lllll}
\hline \multirow{2}{*}{ NIS } & Nam & $\begin{array}{l}\text { Nilai } \\
\text { Aspek } \\
\text { Ekonom }\end{array}$ & $\begin{array}{l}\text { Nilai } \\
\text { Aspek } \\
\text { Presta }\end{array}$ & Bobot \\
& a & $\begin{array}{l}\text { Ki } \\
\text { Keluarg } \\
\text { akadem }\end{array}$ & \\
& & a & ik & \\
\hline $\mathbf{1 1 1}$ & Ahm & 4.38 & 4.3 & 4.338 \\
$\mathbf{1}$ & ad & & 2 & \\
$\mathbf{1 1 1}$ & Heri & 4.58 & 4.4 & 4.496 \\
$\mathbf{2}$ & & & 6 & \\
\hline
\end{tabular}




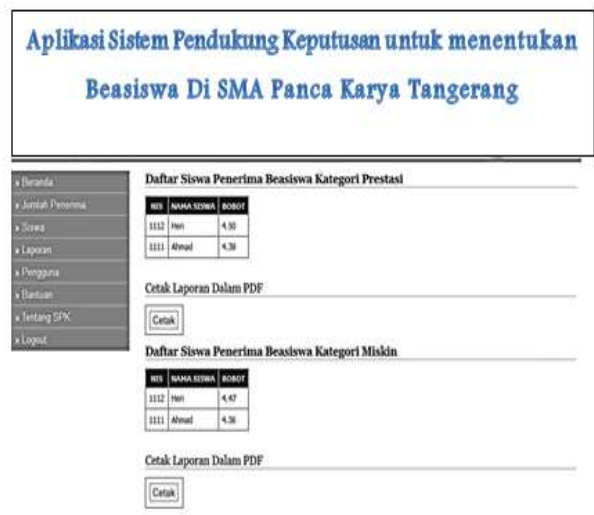

Gambar. 5. Tampilan Laporan Hasil Akhir Daftar Penerima Beasiswa

\section{Kesimpulan}

Dari hasil penelitian yang diperoleh, akurasi dari penggunaan algoritma klasifikasi K-Nearest Neighbor dalam prediksi Bank Marketing sebesar $74,37 \%$ dengan nilai $K=9$, sedangkan untuk akurasi algoritma klasifikasi K-Nearest Neighbor dengan menggunakan feature selection sebesar $89,72 \%$ dengan nilai $\mathrm{K}=3$, sehingga didapat selisih peningkatan akurasi sebesar $15,35 \%$.

\section{Referensi}

Anam, C., \& Santoso, H. B. (2018). Perbandingan Kinerja Algoritma C4 . 5 dan Naive Bayes untuk Klasifikasi Penerima Beasiswa. 8(1), 13-19.

Ary, M. (2019). SATIN - Sains dan Teknologi Informasi Ukuran Akurasi Klasifikasi Penyakit Mesothelioma Menggunakan Algoritma K-Nearest Neighbor dan Backward Elimination. 5(1).

Bode, A. (2017). K-NEAREST NEIGHBOR DENGAN FEATURE SELECTION MENGGUNAKAN BACKWARD ELIMINATION UNTUK PREDIKSI HARGA KOMODITI KOPI ARABIKA. 9, 188-195.

Darmawan, H. (2017). pilih mana menabung di deposito bank atau menabung. Retrieved August 20, 2019, from https://www.finansialku.com/pilih-manamenabung-di-deposito-bank-ataumenabung-di-saham-bank/
Dhikhi, T., Kumar, V., Nadu, T., \& Nadu, T. (2018). Bank Marketing Analysis. 8(11), 4-9.

Hadi, A. F. (2017). ANALISIS DATA MINING UNTUK MENENTUKAN VARIABEL VARIABEL YANG MEMPENGARUHI. 4(1), 108-116.

Kalid, S. N., Khor, K. C., Ng, K. H., \& Ting, C. Y. (2014). Effective Classification for Unbalanced Bank Direct Marketing Data with Over-sampling. i(August), 12-15.

Kosti, S. M., Miloš, Đ., Simi, M. I., \& Kosti, M. V. (2018). Data Mining and Modeling Use Case in Banking Industry. 1-4.

Lestari, M. E. I. (2014). PENERAPAN ALGORITMA KLASIFIKASI NEAREST NEIGHBOR (K-NN) UNTUK MENDETEKSI PENYAKIT JANTUNG. 7(September 2010), 366-371.

Moro, S., Cortez, P., \& Rita, P. (2014). A datadriven approach to predict the success of bank telemarketing. Decision Support Systems.

https://doi.org/10.1016/j.dss.2014.03.00 1

Mustafa, M. S., \& Simpen, I. W. (n.d.). Implementasi Algoritma K-Nearest Neighbor ( KNN ) Untuk Memprediksi Pasien Terkena Penyakit Diabetes Pada Puskesmas Manyampa Kabupaten Bulukumba. VIII(1), 1-10.

Pengetahuan, J., \& Komputer, D. A. N. T. (2017). PENERAPAN METODE KNEAREST NEIGHBOR PADA PENENTUAN GRADE DEALER. 2(2), 108-112.

Ruangthong, P., \& Jaiyen, S. (2015). Bank Direct Marketing Analysis of Asymmetric Information Based on Machine Learning. 93-96.

Rusdiawan, T. W., Alamsyah, A., Manajemen, M., Ekonomi, F., Bisnis, D., \& Telkom, U. (2019). EKSPLORASI DATA PELANGGAN, UNTUK KONTEKSTUAL MARKETING VOICE OVER LONG TERM EVOLUTION PT . TELKOMSEL MENGGUNAKAN METODE CLUSTERING K-MEANS CUSTOMER DATA EXPLORATION , FOR 
CONTEXTUAL MARKETING VOICE OVER LONG TERM EVOLUTION PT. TELKOMSEL USING K-MEANS CLUSTERING METHOD. 6(1), 537-544.

Ula, R. (2018). PENGARUH CAPITAL
ADEQUACY RATIO ( CAR ), INFLASI , DAN SUKU BUNGA SERTIFIKAT BANK INDONESIA ( SBI ) TERHADAP TINGKAT SUKU BUNGA DEPOSITO BERJANGKA ( Studi Pada Perusahaan Bank Pembangunan Daerah di Indonesia Periode 2010-2015 ). 56(1). 